\title{
Cloning and Heterologous Expression of Genes from the Kinamycin Biosynthetic Pathway of Streptomyces murayamaensis
}

\author{
Steven J. Gould, ${ }^{*, a, b, \dagger}$ SeOng-Tshool HonG $^{a, \dagger \dagger}$ and John R. Carney ${ }^{\mathbf{b}}$ \\ Departments of a Biochemistry and Biophysics and of ${ }^{b}$ Chemistry Oregon State University, \\ Corvallis, Oregon 97331-4003, U.S.A.
}

(Received for publication July 22, 1997)

\begin{abstract}
The genes for most of the biosynthesis of the kinamycin antibiotics have been cloned and heterologously expressed. Genomic DNA of Streptomyces murayamaensis was partially digested with $M b o I$ and a library of $\sim 40 \mathrm{~kb}$ fragments in E. coli XL1-BlueMR was prepared using the cosmid vector pOJ446. Hybridization with the act I probe from the actinorhodin polyketide synthase genes identified two clusters of polyketide genes. After transferal of these clusters to $S$. lividans ZX7, expression of one cluster was established by HPLC with photodiode array detection. Peaks were identified from the kin cluster for dehydrorabelomycin, kinobscurinone, and stealthin $\mathrm{C}$, which are known intermediates in kinamycin biosynthesis. Two shunt metabolites, kinafluorenone and seongomycin were also identified. The structure of the latter was determined from a quantity obtained from large-scale fermentation of one of the clones.
\end{abstract}

Members of the genus Streptomyces produce well over half of the known antibiotics of natural origin. Of these, polyketide-derived metabolites are amongst the most numerous and diverse, and include many clinically important members, such as erythromycin, tetracycline, and doxorubicin. Assembly of the skeletons of such compounds by oligomerization of small precursor fatty acid thioesters to form polyketide backbones is carried out by polyketide synthases (PKSs). These are made up of either large multi-functional enzymes (type I PKSs) or multi-enzyme complexes (type II PKSs). Molecular genetic analyses have revealed that the genes for each PKS are clustered in a relatively small region of DNA. ${ }^{1)}$ The gene clusters for numerous polyketide pathways have been detected by hybridization with probes derived from genes coding for proteins that catalyze equivalent reactions in different pathways. ${ }^{2,3)}$

We have been studying the biosynthesis of a number of antibiotics derived from benz $[a]$ anthraquinones (i.e. angucyclinones $^{4 \sim 77}$. One of these yields the kinamycins, which are broad spectrum antibiotics with modest cytotoxicity that were first reported from Streptomyces murayamaensis (e.g. kinamycin D, 1, Figure 1). ${ }^{5,8,9)}$
Kinamycin biosynthesis proceeds via dehydrorabelomycin, ${ }^{7)} 2$, followed by ring contraction to the recently discovered $^{10 \sim 12)}$ benzo[b]fluorene skeleton and then by extensive further modifications. We have also identified prekinamycin, ${ }^{5,13)} 3$, and ketoanhydrokinamycin, ${ }^{14)} \mathbf{4}$, as likely intermediates in the pathway, have demonstrated kinobscurinone, ${ }^{15)} 5$, stealthin $\mathrm{C},{ }^{16)} \mathbf{6}$, and kinamycins $\mathrm{F}$ and $\mathrm{E},{ }^{14)} 7$ and 8 , respectively, to be intermediates, and have isolated a large acetyltransferase that sequentially acetylates kinamycin $\mathrm{F}$ at $\mathrm{C}-4$ and then at C-2. ${ }^{17)}$ Two other actinomycetes are known to produce kinamycins. ${ }^{18,19)}$ We now report the cloning and heterologous expression of most of the kinamycin gene cluster from $S$. murayamaensis in $S$. lividans $Z \mathrm{ZX} 7,{ }^{20)}$ as evidenced by production of $\mathbf{2 , 5}$, and $\mathbf{6}$ by the recombinant strains.

\section{Materials and Methods}

Bacterial Strains and Plasmids Used

Streptomyces murayamaensis was a gift from Professor S. ŌMURA, Kitasato University. S. lividans ZX7, used as the recombinant host strain, was obtained from Professor

Present address: † Natural Products Drug Discovery, MRL Laboratories, PO Box 2000, RY80Y-320, Rahway, NJ 07065.

${ }^{\dagger \dagger}$ Dept. of Neurology, Northwestern University Medical School, Tarry 13-715, 303 E. Chicago Ave, Chicago, IL 60611 . 
Fig. 1. Current understanding of kinamycin D biosynthesis.<smiles>CC#COC(C)=O</smiles><smiles>Cc1cc(O)c2c3c(c(O)cc2c1)C(=O)c1c(O)cccc1C3=O</smiles>

2<smiles>Cc1cc(O)c2c3c(=O)c4cccc(O)c4c(=O)c=3c(=O)c2c1</smiles><smiles>Cc1cc(O)c2c(c1)C(N)=C1C(=O)c3c(O)cccc3C(O)=C12</smiles><smiles></smiles><smiles>Cc1cc(O)c2c(c1)C(N)=C1C(=O)c3c(O)cccc3C(=O)C12</smiles>

3<smiles>C[C@]12O[C@H]1[C@@H](O)c1c(c(=N)c3c(=O)c4cccc(O)c4c(=O)c1=3)C2=O</smiles><smiles>CC(=O)O[C@H]1C2=C(C3=C(C(=O)c4c(O)cccc4C3=O)[C@@H]2O)[C@@H](O)C(O)[C@@]1(C)O</smiles><smiles>CC(=O)O[C@H]1c2c(c3c(=O)c4cccc(O)c4c(=O)c=3c2=[N+]=[N-])[C@@H](O)[C@@H](O)[C@@]1(C)O</smiles>

David Hopwood (John Innes Center, England). The cosmid pOJ446, used for cosmid library construction, was obtained from Lilly Research Laboratories. E. coli XL1-Blue MR and pBluescript ${ }^{\circledR}$ II KS ${ }^{+}$were purchased from Stratagene. E. coli DH5 $\alpha$ was purchased from Clontech, and pGEM11zf(+) was purchased from Promega.

Culture Conditions for S. murayamaensis and S. lividans

S. murayamaensis or S. lividans was propagated on ISP4 agar $+0.01 \%$ yeast extract ${ }^{21)}$ and in R2YE ${ }^{22)}$ at $29^{\circ} \mathrm{C}$ for spore preparation, or in YEME liquid media ${ }^{22)}$ at 27 and at $29^{\circ} \mathrm{C}$ for genomic DNA preparation.

\section{Genomic DNA Isolation}

Genomic DNA was prepared from S. murayamaensis as follows: mycelia from a $50 \mathrm{ml}$ culture grown in YEME containing $0.5 \%$ glycine were collected by centrifugation, washed twice with $10.3 \%$ sucrose, and resuspended in $10 \mathrm{ml}$ of a solution containing $25 \mathrm{~mm}$ Tris ( $\mathrm{pH} \mathrm{8.0),} 50$ mu glucose, $10 \mathrm{~mm}$ EDTA (pH 8.0), $20 \mu \mathrm{g} / \mathrm{ml}$ RNase, $10 \mathrm{mg} / \mathrm{ml}$ lysozyme, and $10 \mathrm{mg} / \mathrm{ml}$ achromopeptidase
(Sigma). After 5 10 minutes incubation at room temperature, proteinase $\mathrm{K}$ was next added $(0.5 \mathrm{mg} / \mathrm{ml})$ and the mixture incubated at $50^{\circ} \mathrm{C}$ overnight. The mixture was then worked up in standard fashion, and the genomic DNA was dissolved in $3 \mathrm{ml}$ TE buffer.

\section{Preparation of a Cosmid Library of S. murayamaensis}

Genomic DNA from $S$. murayamaensis was digested with BamHI, KpnI, and PstI, and the digested DNA's were separated by electrophoresis. Southern blots were probed with ${ }^{32} \mathrm{P}$-radiolabeled $a c t \mathrm{I}$, the ketoacylsynthase gene from the actinorhodin pathway of $S$. coelicolor $\mathrm{A} 3(2),{ }^{23)}$ which was present in $\mathrm{pIJ} 2345$, and washed at moderate stringency $(2 \times \mathrm{SSC} / 1 \% \mathrm{SDS})$. The probe hybridized moderately strongly with four bands in the Bam HI digest (5.6, 4.3, 2.6, and $0.5 \mathrm{~kb}$ ), and weakly with a few more. The probe hybridized moderately strongly with two large bands in the KpnI and Pst I digests.

Genomic DNA from $S$. murayamaensis was partially digested with $M b o \mathrm{I} .10 \sim 20 \mu \mathrm{g}$ of the partially digested DNA fragments in TE buffer were ligated with $4 \sim 6 \mu \mathrm{g}$ of pOJ446 that had been digested with BamHI and with HpaI, using T4 DNA ligase. The ligated DNA was 
packaged in vitro using Giga Pack II XL packaging extract (Stratagene) and then used to transfect $E$. coli XL1-BlueMR. The manufacturer's protocol was followed.

\section{Colony Hybridization of the Cosmid Libraries}

Approximately 6000 E. coli colonies from the S. murayamaensis cosmid library were spread on dried nylon membranes (138 $\mathrm{mm}$ diameter, Amersham) as described by the manufacturer. After spreading the inoculum, the membrane was transferred onto an Luria-Bertani (LB)-agar plate containing $100 \mu \mathrm{g} / \mathrm{ml}$ apramycin and incubated overnight at $37^{\circ} \mathrm{C}$. The cosmid library was replicated to new nylon membranes, lysed, and hybridized as described by the manufacturer, using ${ }^{32}$ P-labeled actI.

Thirty-eight hybridizing clones were obtained and restriction mapping with $B a m \mathrm{HI}$ and EcoRI showed that they segregated into two non-overlapping sets: 15 clones in one cluster $(\mathrm{kin})$ and 23 clones for the other. The first contained three act I homologous Bam HI fragments (4.3, 2.6 , and $0.5 \mathrm{~kb}$ ), and the second contained a single, $5.6 \mathrm{~kb}$, act I homologous BamHI fragment.

Transformation of S. lividans ZX7 with Recombinant Plasmids

Plasmid DNAs were isolated according to standard procedures $^{24)}$ from $1.5 \mathrm{ml}$ overnight cultures in LB broth plus $15 \mu \mathrm{g} / \mathrm{ml}$ of apramycin. Correct inserts were confirmed by restriction enzyme analysis. $S$. lividans protoplasts $\left(5 \times 10^{8}\right.$ in $50 \mu \mathrm{l}$ P-buffer $)$ were mixed with $5 \mu \mathrm{l}$ of recombinant plasmid $(0.01 \sim 0.1 \mu \mathrm{g} / \mu \mathrm{l})$, followed by 200 $\mu$ of T-buffer, and the mixture was then spread on R2YE agar. $^{22)}$ Transformants were detected by overlaying $2.5 \mathrm{ml}$ of soft nutrient agar $(600 \mu \mathrm{g} / \mathrm{ml}$ apramycin $)$ per plate $14 \sim 20$ hours later.

\section{Fermentation of $S$. lividans and Transformants}

Colonies of each organism were inoculated into $5 \mathrm{ml}$ of YEME containing $6 \mu \mathrm{g} / \mathrm{ml}$ of apramycin for transformants. After incubation for $3 \sim 4$ days at $29^{\circ} \mathrm{C}$, $260 \mathrm{rpm}, 0.25 \mathrm{ml}$ of the seed culture was used to inoculate $5 \mathrm{ml}$ of three production media, each in $18 \mathrm{ml}$ culture tubes: glucose Proflow-salt (GPS), ${ }^{25)}$ glycerol-asparagine (GA), ${ }^{26)}$ and YEME, each containing $6 \mu \mathrm{g} / \mathrm{ml}$ of apramycin. The rest of the transformant cultures were used for plasmid mini-preps to confirm the presence of the correct plasmids. All cultures were incubated at $29^{\circ} \mathrm{C}$, $300 \mathrm{rpm}$, for both 5 and 9 days.
Analysis of the Metabolites

Cultures were acidified ( $\mathrm{pH} 2.5 \sim 3.0$ ) with $0.1 \mathrm{~N} \mathrm{HCl}$, extracted with $3 \mathrm{ml}$ of EtOAc, and the extracts dried (SpeedVac centrifuge) and taken up in $100 \mu \mathrm{l}$ of $10 \%$ $\mathrm{MeOH} / \mathrm{CH}_{2} \mathrm{Cl}_{2}$. An aliquot $(10 \mu \mathrm{l})$ of each extract was analyzed by reverse phase HPLC with a Waters Assoc. $600 \mathrm{E}$ gradient pump. The metabolites were separated on a Waters NovaPak $\mathrm{C}_{18}$ radial compression column $(0.8 \times 10 \mathrm{~cm}, 4 \mu \mathrm{m})$ using a gradient of $5 \sim 95 \%$ acetonitrile in water containing $0.1 \%$ acetic acid over a period of 30 minutes at $1.5 \mathrm{ml} /$ minute. Detection was by photodiode array using either a Waters $990+$ detector or a Waters 996 detector (retention times: seongomycin, 13.39; 6, 16.26; kinafluorenone, 16.70; 5, 20.9; 2, 22.09 minutes).

\section{Preparation of a Physical Map of kin Cluster}

Four cosmids of the kin cluster that produced recognizable $S$. murayamaensis metabolites were digested with combinations of XbaI, SpeI, and EcoRI, both individually and in pairs. The first two are in the pOJ446 polylinker; no sites internal to the inserts were observed. EcoRI provided a rough restriction map. The $15.5 \mathrm{~kb}$ SpeI-EcoRI fragment of pSH1590 was subcloned using pBluescript II $\mathrm{KS}^{+}$to generate pSH1590.10. The $6.5 \mathrm{~kb}$ and $16.2 \mathrm{~kb}$ EcoRI fragments of pSH1500, and the $8.7 \mathrm{~kb}$ EcoRI-XbaI fragment of pSH1500 were subcloned using pGEMzf $(+)$ to generate pSH1500.20, pSH1500.30, and pSH1500.40, respectively. Each of these was restriction mapped with BamHI and PstI. Two small EcoRI fragments $(0.7$ and $0.3 \mathrm{~kb})$ were subsequently identified and mapped to positions between pSH1500.30 and pSH1500.40. Southern blots of the digests were probed with ${ }^{32} \mathrm{P}$-labeled $a c t \mathrm{I}$ and ${ }^{32} \mathrm{P}$-labeled actIII (the 9-ketoreductase gene of $S$. coelicolor A3(2) contained on pIJ2346). ${ }^{23)}$

\section{Southern Hybridization}

Southern blots of recombinant cosmids were performed using Hybond-N nylon membranes (Amersham), and the blots were hybridized with the actI probe, as recommended by the manufacturer.

\section{Other Molecular Biological Techniques}

Plasmid DNA isolations from $E$. coli and preparation of $E$. coli competent cells were performed according to standard procedures. ${ }^{24)}$ Restriction enzymes, DNA ligase and calf intestinal alkaline phosphatase were purchased from Gibco BRL, New England Biolabs, United States Biochemical, Promega and Boehringer- 
Mannheim, and used according to the manufacturers' instructions. Plasmid isolation and protoplast preparation from $S$. lividans were carried out according to HopwOOD et al. ${ }^{22)}$

\section{Results}

S. murayamaensis proved much less tractable for extraction of genomic DNA than other species, such as S. lividans. To overcome this problem, a simple and efficient protocol was developed that has proven to be of general utility. Thus, mycelia were briefly treated with lysozyme and achromopeptidase, followed by complete digestion with proteinase $\mathrm{K}$ overnight at $50^{\circ} \mathrm{C}$. Genomic DNA from $S$. murayamaensis was then digested with a variety of enzymes as described in the Materials and Methods Section, and Southern blots were probed with ${ }^{32} \mathrm{P}$-radiolabeled act $\mathrm{I}$, the ketoacylsynthase gene from the actinorhodin pathway of $S$. coelicolor A3(2). ${ }^{23)}$

\section{Isolation of Two PKS Gene Clusters}

from $S$. murayamaensis

A S. murayamaensis cosmid library containing fragments of $\sim 30 \sim 40 \mathrm{~kb}$ was constructed using a partial digest of genomic DNA ligated into a cosmid shuttle vector. ${ }^{27)}$ Screening this library with the actI probe identified thirty-eight hybridizing clones, and restriction mapping and Southern hybridization results clearly showed that the clones segregated into two non-overlapping sets.

\section{Expression of the kin Genes in S. lividans ZX7}

All fifteen cosmid clones from the cluster that proved to contain the kin genes were used to transform S. lividans $\mathrm{ZX} 7,{ }^{20)}$ derived from $S$. lividans JT46. ${ }^{28)}$ Four of these transformants produced recognizable $S$. murayamaensis metabolites (Table 1), including dehydrorabelomycin. One major metabolite had previously been observed as a very minor metabolite in $S$. murayamaensis mutant $\mathrm{MC} 1,{ }^{11)}$ a kinamycin-deficient strain that still produces dehydrorabelomycin and kinafluorenone. It was obtained in sufficient quantity from a large-scale fermentation of $S$. lividans $/ \mathrm{pSH} 1580$ for its characterization as a benzo $[b]$ fluorene analogous to stealthin $\mathrm{C}$, but containing an $\mathrm{N}$-acetylcysteine residue at C-5, and has been named seongomycin. ${ }^{29)}$ Most importantly, the transformants containing pSH1590 or pSH1610 also produced kinobscurinone, stealthin $\mathrm{C}$, and kinafluorenone, identified by photodiode array-detected HPLC. The first two are intermediates in kinamycin biosynthesis, and the last is a shunt metabolite.

All twenty-three cosmid clones from the other cluster were also used to transform $S$. lividans ZX7. However, no new metabolites were produced by these transformants.

Table 1. Bacterial strains and plasmids used in this study.

\begin{tabular}{|c|c|c|}
\hline Strains or plasmids & Relevant characteristics & Source or reference \\
\hline \multicolumn{3}{|l|}{ Bacterial strains } \\
\hline S. murayamaensis & Kinamycin and murayaquinone producer & ŌMURA et al. (1973) \\
\hline E. coli XL1-BlueMR & $\begin{array}{l}\Delta(\text { mcr } A) 183, \Delta(\text { mcrCB-hsdSMR-mrr }) 173, \text { end } A 1, \\
\text { supE44, thi-1, recA1, gyrA96, relA1, lac }\end{array}$ & Stratagene \\
\hline S. lividans $\mathrm{ZX7}$ & Host for expression test $\left(\mathrm{SLP}^{-}, \mathrm{SLP}^{-}\right)$ & John Innes Institute \\
\hline \multicolumn{3}{|l|}{ Plasmids } \\
\hline pOJ446 & E. coli-Streptomyces shuttle cosmid & BIERMAN et al. (1992) \\
\hline pBluescript II $\mathrm{KS}^{+}$ & & Stratagene \\
\hline pGEM11zf( + ) & & Promega \\
\hline pIJ2345 & pBR329 with a $2.2 \mathrm{~kb}$ actI insert & John Innes Centre \\
\hline pIJ2346 & pBR329 with a $1.1 \mathrm{~kb}$ actIII insert & John Innes Centre \\
\hline pSH1500 & $\begin{array}{l}\text { kin }+ \text { pOJ } 446, \text { produces dehydrorabelomycin and } \\
\text { seongomycin in } S . \text { lividans }\end{array}$ & This work \\
\hline pSH1580 & $\begin{array}{l}\text { kin }+ \text { pOJ } 446, \text { produces dehydrorabelomycin and } \\
\text { seongomycin in } S . \text { lividans }\end{array}$ & This work \\
\hline pSH1590 & $\begin{array}{l}\text { kin }+ \text { pOJ } 446 \text {, produces dehydrorabelomycin, seongomycin, } \\
\text { kinafluorenone, kinobscurinone, and stealthin } \mathrm{C} \text { in } \\
\text { S. lividans }\end{array}$ & This work \\
\hline pSH1610 & $\begin{array}{l}\text { kin }+ \text { pOJ } 446, \text { produces dehydrorabelomycin, seongomycin, } \\
\text { kinafluorenone, kinobscurinone, and stealthin } \mathrm{C} \text { in } \\
\text { S. lividans }\end{array}$ & This work \\
\hline
\end{tabular}


Four inserts from the kin cosmids producing identifiable metabolites contained the same two 16.2 and $6.5 \mathrm{~kb}$ $E c o$ RI fragments. The two cosmids that yielded the more advanced metabolites (e.g. 5 and 6), have SpeI-EcoRI fragments approximately $2.0 \sim 2.5 \mathrm{~kb}$ longer than the other two cosmids. This may indicate that genes for advanced stages of the pathway are at the SpeI end of the inserts. Using two of the cosmid clones, four subclones were prepared that spanned the overlapping region that contained the available kin genes. A physical map of each was generated from digests with BamHI and Pst I, and the regions containing DNA homologous to actI and to actIII were identified on pSH1500.30 by hybridization experiments (Figure 2).

\section{Discussion}

S. murayamaensis produces two different groups of aromatic decaketides, ${ }^{5,9,30)}$ one of which - the kinamycins- is derived from the angucyclinone dehydrorabelomycin. Since typical aromatic polyketide biosynthetic gene clusters encompass approximately $20 \sim 35 \mathrm{~kb}$, we constructed a library of approximately $40 \mathrm{~kb}$ fragments of S. murayamaensis genomic DNA. This approach has previously proven very successful, and we have cloned and heterologously expressed the genes for two other complete angucyclinone pathways, ${ }^{31)}$ those for tetrangulol/tetrangomycin ${ }^{32)}$ and for antibiotic PD1 16740. ${ }^{33)}$

The studies reported here have revealed that $S$. murayamaensis contains at least two clusters of PKS genes. Heterologous production of kinamycin biosynthetic intermediates was obtained from only one cluster. It is noteworthy that $S$. coelicolor has two known PKS clusters, one for actinorhodin ${ }^{34)}$ and one for a spore pigment, ${ }^{35)}$ and the genes for the latter product are not expressed during actinorhodin production. ${ }^{36)}$ We have also found two PKS clusters in S. rimosus NRRL 3016 and in S. WP 4669; in each case heterologous expression was obtained from only one cluster. ${ }^{31)}$ The urdamycin producer $S$. fradiae Tü 2717 also contains two. ${ }^{37)}$ It is possible that the unexpressed cluster in each of these organisms may code for a spore pigment. Hybridization probes from the actinorhodin (act) pathway were used, and this may have biased the results. Thus, $S$. murayamaensis is unusual in this group of organisms in that it also produces another aromatic decaketide, murayaquinone ${ }^{30)}$ under normal conditions. Incorporation of isotopically-labeled acetates ${ }^{38)}$ has indicated that its biosynthesis involves ketone reductions and a folding of the acyclic decaketide intermediate in a manner very different from that found in the isochromanquinones (e.g. actinorhodin), the anthracyclines, or the angucyclines.

Fig. 2. Physical map of the kin gene cluster.

$\mathrm{B}=\operatorname{Bam} \mathrm{HI}, \mathrm{EI}=E c o \mathrm{RI}, \mathrm{M}=\mathrm{MboI}, \mathrm{P}=P s t \mathrm{I}$.

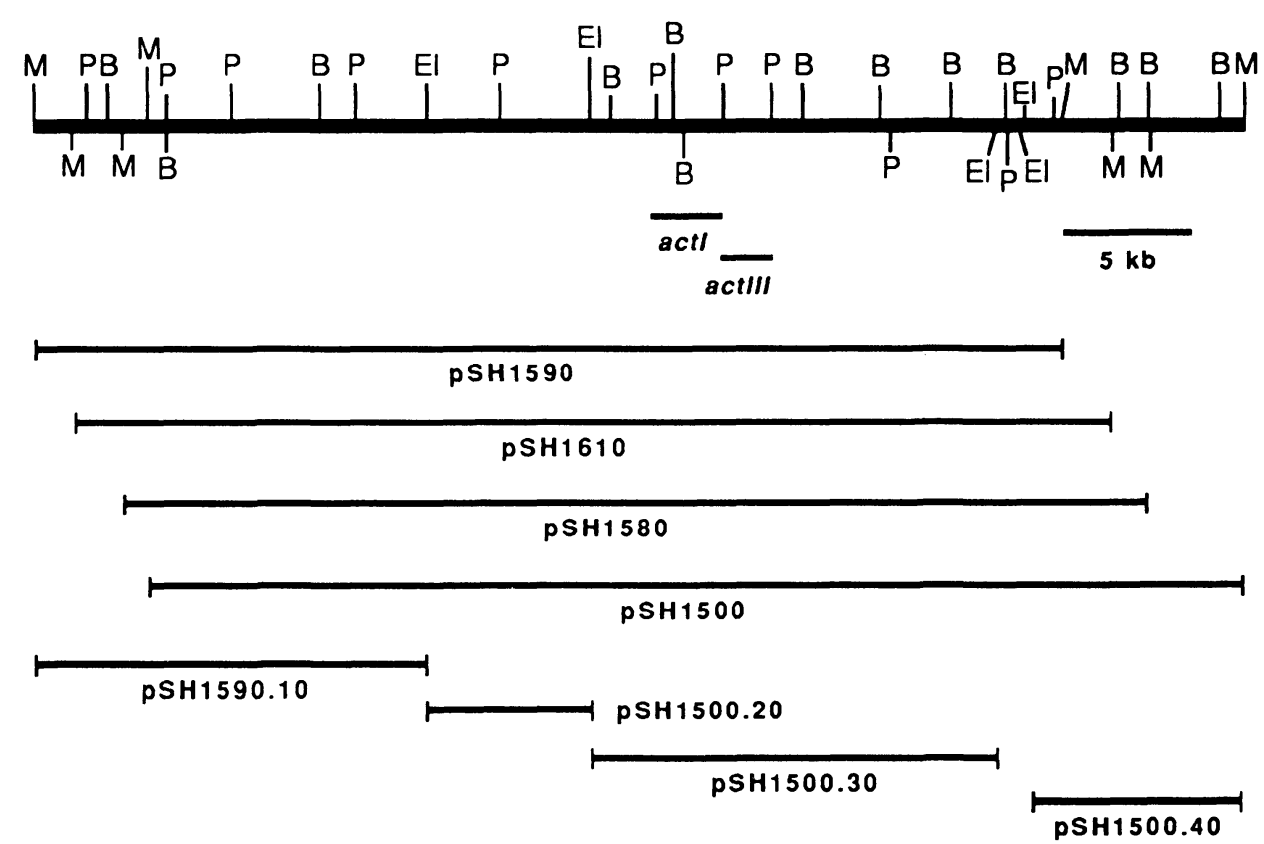

Cosmids and subclones used for mapping are shown below the genomic DNA. Regions hybridizing with either actI or actIII are indicated; the orientation is arbitrarily chosen to conform to that previously observed for other angucyclinone PKS genes. 
Fig. 3. Potential relationship of the "cleavase" enzymes in the kinamycin and jadomycin biosynthetic pathways.

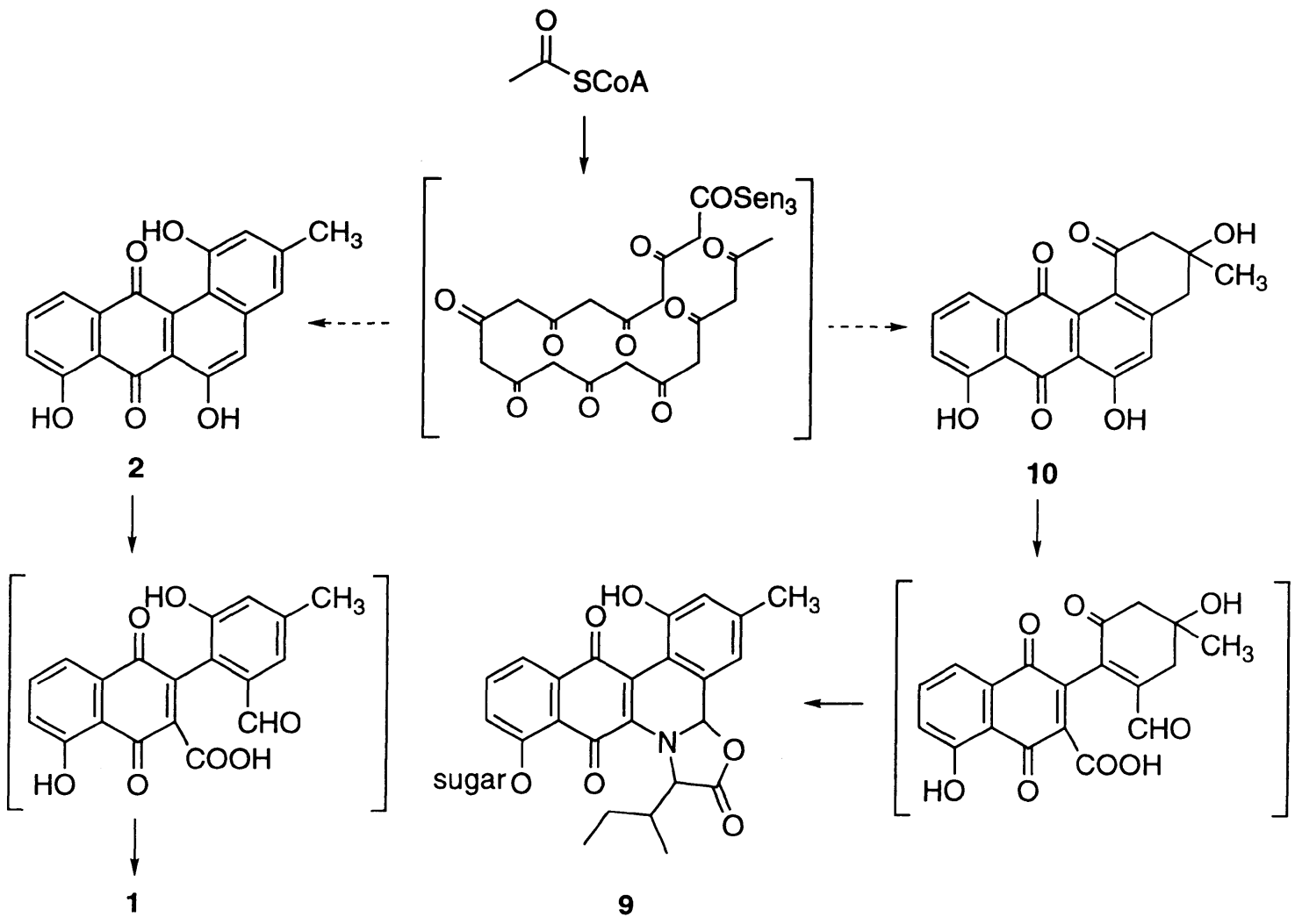

Thus, it is possible that the murayaquinone PKS genes would not hybridize with the act genes at a useful stringency.

Heterologous production of metabolites representing the bulk of the kinamycin D pathway has now been obtained. Thus, accumulations of the kinamycin intermediates 2, 5 and 6 were observable, as were the shunt metabolites kinafluorenone and seongomycin. Although other aromatic polyketide gene clusters have been fully encompassed by $40 \mathrm{~kb}$ of DNA, this may prove not to be the case for kinamycin $\mathrm{D}$. We have previously isolated an apparently multifunctional protein, or complex of proteins, of $>670 \mathrm{KDa}$ from $S$. murayamaensis that catalyzes the sequential acetylations that convert kinamycin $\mathrm{F}$ to kinamycin D via kinamycin $\mathrm{E}$. If a single peptide, such a protein would by itself add $15 \sim 20 \mathrm{~kb}$ of DNA to the cluster.

Although the complete kinamycin D gene cluster is not yet in hand, the portion that is available contains the gene required for cleaving the $\mathrm{C}$-ring of the angucyclinone skeleton, as well as the gene(s) for generating the benzo[b]fluorene skeleton. VINING et al. has reported $^{39)}$ disruption of the gene for the C-ring cleavage enzyme in the jadomycin (e.g. jadomycin $\mathrm{B}, 9$ ) pathway, with concomitant accumulation of rabelomycin, $\mathbf{1 0}$. They have suggested that this is the cleavage substrate, which would require dehydration and aromatization of the D-ring at a later stage. With the availability of the "cleavase" gene for the kinamycin pathway, it will be possible to determine the relationship of these two pathways (Figure 3).

The cloned DNA also contains the gene(s) for introduction of the first nitrogen of the eventual diazo group that characterizes all of the kinamycins. Although kinobscurinone has been detected in S. murayamaensis fermentations and, in labeled form, has been incorporated into kinamycin $\mathrm{D},{ }^{15}$ ) the actual amination substrate cannot yet be precisely identified. The compounds in this group can exist in the hydroquinone, quinone, and semi-quinone forms under ambient conditions. With such small differences in redox potentials, the amination substrate could be kinobscurinone, in which case a glutamine- or ammonia-dependent amidotransferase might be considered more likely, or it could be the hydroquinone, in which case a pyridoxamine phosphate-dependent transaminase would be more likely 
Fig. 4. Potential involvement of either an aminotransferase or amidotransferase in the formation of stealthin C.

a: Transaminase, b: amidotransferase; c: tautomerase, d: oxidase, e: hydrolase, $f:[1,2]$ reductase, g: $[1,6]$ reductase.<smiles>Cc1cc(O)c2c(c1)/C(=N\CBr)c1c-2c(O)c2cccc(O)c2c1O</smiles>

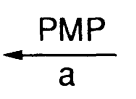<smiles>Cc1cc(O)c2c(c1)C(=O)c1c-2c(O)c2cccc(O)c2c1O</smiles><smiles>Cc1cc(O)c2c(c1)C(=N)c1c-2c(O)c2ccc(N)c(O)c2c1O</smiles><smiles>CCCO[GeH2]</smiles><smiles>Cc1cc(O)c2c(c1)C(N)=C1C(=O)c3c(O)cccc3C(O)=C12</smiles>

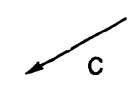<smiles>[14CH2]C[14CH2]</smiles><smiles></smiles><smiles>Cc1cc(O)c2c3c(=O)c4c(O)cccc4c(=O)c=3c(=O)c2c1</smiles><smiles>[Mg][Mg][Mg]</smiles><smiles>Cc1cc(O)c2c3c(=O)c4c(O)cccc4c(=O)c=3c(=N)c2c1</smiles>

5

(Figure 4). The availability of the gene(s) for this portion of the pathway bodes well for obtaining the relevant enzymes to resolve this issue.

\section{Acknowledgments}

This work was supported by Public Health Service grant GM 31715 to S.J.G. from the National Institute of General Medical Sciences. Professors S. ŌMURA and U. HornemanN of Kitasato University and the University of Wisconsin are thanked for the strain of Streptomyces murayamaensis. ${ }^{1} \mathrm{H}$ NMR spectra were obtained using a Bruker AC 300 spectrometer purchased in part through grants from the Public Health Service Division of Research Resources (RR04039-01) and the National Science Foundation (CHE-8712343) to Oregon State University.

\section{References}

1) Hopwood, D. A. \& D. H. Sherman: Molecular genetics of polyketides and its comparison to fatty acid biosynthesis. Annu. Rev. Genet. 24: $37 \sim 66,1990$

2) Katz, L. \& S. Donadio: Polyketide synthesis: prospects for hybrid antibiotics. Ann. Rev. Microbiol. 47: 875 912, 1993

3) Malpartida, F.; S. E. Hallam, H. M. Kieser, H. Motamedi, C. R. Hutchinson, M. J. Butler, D. A. Sugden, M. Warren, C. Mckillop, C. R. Bailey, G. O. Humphreys \& D. A. HopwoOD: Homology between
Streptomyces genes coding for synthesis of different polyketides used to clone antibiotic biosynthetic genes. Nature 325: $818 \sim 821,1987$

4) Gould, S. J. \& X.-C. ChENG: New benz[a]anthraquinone secondary metabolites from Streptomyces phaeochromogenes. J. Org. Chem. 59: 400 405, 1994

5) Gould, S. J.; N. Tamayo, C. R. Melville \& M. C. Cone: Revised structures for the kinamycin antibiotics: 5diazobenzo $[b]$ flourenes rather than benzo $[b]$ carbazole cyanamides. J. Am. Chem. Soc. 116: 2207 2208, 1994

6) RoHR, J. \& R. ThIERICKE: Angucycline group antibiotics. Nat. Prod. Rep. 9: 103 137, 1992

7) Seaton, P. J. \& S. J. Gould: Kinamycin biosynthesis. Derivation by excision of an acetate unit from a single-chain decaketide intermediate. J. Am. Chem. Soc. 109: 5282 5284, 1987

8) Mithani, S.; G. Weeratunga, N. J. Taylor \& G. I. DMITRIENKo: The kinamycins are diazofluorenes and not cyanocarbazoles. J. Am. Chem. Soc. 116: 2209 2210, 1994

9) Omura, S.; A. Nakagawa, H. Yamada, T. Hata, A. FurUSAKI \& T. WATANABE: Structures and biological properties of kinamycin A, B, C, and D. Chem. Pharm. Bull. 21: $931 \sim 940,1973$

10) Aoyama, T.; W. Zhao, F. Kojima, Y. Muraoka, H. Naganawa, T. Takeuchi \& T. Aoyagi: Cysfluoretin, a new inhibitor of glutathione $S$-transferase, produced by Streptomyces sp. MI384-DF12. J. Antibiotics 46: 1471 1474,1993 
11) Cone, M. C.; C. R. Melville, M. P. Gore \& S. J. Gould: Kinafluorenone, a benzo $[b]$ fluorenone isolated from the kinamycin producer Streptomyces murayamaensis. J. Org. Chem. 58: $1058 \sim 1061,1993$

12) Shin-ya, K.; K. Furihata, Y. Teshima, Y. Hayakawa \& H. SETO: Structures of stealthins A and B, new free radical scavengers of microbial origin. Tetrahedron Lett. 33: $7025 \sim 7028,1992$

13) Gould, S. J.; J. Chen, M. C. Cone, M. P. Gore, C. R. Melville \& N. TAmayo: Identification of prekinamycin in extracts of Streptomyces murayamaensis. J. Org. Chem. 61: $5720 \sim 5721,1996$

14) Seaton, P. J. \& S. J. Gould: New products related to kinamycin from Streptomyces murayamaensis: 2. Structures of pre-kinamycin, keto-anhydrokinamycin, and kinamycins E and F. J. Antibiotics 42: 189 197, 1989

15) Gould, S. J. \& C. R. Melville: Kinamycin biosynthesis. Synthesis, detection, and incorporation of kinobscurinone, a benzo $[b]$ fluorenone. Bioorg. Med. Chem. Lett. 6: $51 \sim 54,1995$

16) Gould, S. J.; C. R. Melville, M. C. Cone, J. Chen \& J. R. CARneY: Kinamycin biosynthesis. Synthesis, isolation, and incorporation of stealthin $\mathrm{C}$, an aminobenzo[b]fluorene. J. Org. Chem. 62: 320 324, 1997

17) Gould, S. J.; T. O’hare, P. J. Seaton, J. Soodsma \& Z. TANG: Kinamycin acetyltransferase I from Streptomyces murayamaensis, an apparently large, membrane-associated enzyme. Bioorg. Med. Chem. 4: 987 994, 1996

18) Isshiki, K.; T. Sawa, H. Naganawa, N. Matsuda, S. HatToRi, M. Hamada \& T. TaKeUCHI: 3- $O$-Isobutyrylkinamycin $\mathrm{C}$ and 4-deacetyl-4- $O$-isobutyrylkinamycin $\mathrm{C}$, new antibiotics produced by a Saccharothrix species. J. Antibiotics 42: $467 \sim 469,1989$

19) Smitka, T. A.; R. Bonjouklian, Jr., T. J. Perun, A. H. Hunt, R. S. Foster, J. S. Mynderse \& R. C. YaO: A83016A, a new kinamycin type antibiotic. J. Antibiotics 45: 581 583, 1989

20) Zhou, X.; Z. Deng, D. A. Hopwood \& T. Kieser: Streptomyces lividans 66 contains a gene for phage resistance which is similar to the phage I ea59 endonuclease gene. Mol. Microbiol. 12: 789 797, 1994

21) Stirling, E. B. \& D. Gottlieb: Methods for characterization of Streptomyces species. Inter. J. System. Bacteriol. 16: $313 \sim 340,1966$

22) Hopwood, D. A.; M. J. BibB, K. F. Chater, T. Kieser, C. J. Bruton, H. M. Kieser, D. J. Lydiate, C. P. SMith, J. M. WARD \& H. SChrempF: Genetic Manipulation of Streptomyces: A Laboratory Manual. John Innes Foundation, Norwich, 1985

23) Fernandez-Moreno, M. A.; E. Martinez, L. Boto, D. A. Hopwood \& F. Malpartida: Nucleotide sequence and deduced functions of a set of cotranscribed genes of Streptomyces coelicolor A3(2) including the polyketide synthase for the antibiotic actinorhodin. J. Biol. Chem. 267: $19278 \sim 19290,1992$

24) SambrooK, J.; E. F. Fritsch \& T. Maniatis: Molecular Cloning, a Laboratory Manual. Cold Spring Harbor Laboratory Press, Cold Spring Harbor, 1989

25) Dekleva, M. L. \& W. 'R. STrohl: Glucose-stimulated acidogenesis by Streptomyces peucetius. Can. J. Microbiol. 33: $1129 \sim 1132,1987$
26) Cone, M. C.; P. J. Seaton, K. A. Halley \& S. J. Gould: New products related to kinamycin from Streptomyces murayamaensis: 1. Taxonomy, production, isolation and biological properties. J. Antibiotics 42: 179 188, 1989

27) Bierman, M.; R. Logan, K. O'Brien, E. T. Seno, R. NAGARAJA RAO \& B. E. SCHONER: Plasmid cloning vectors for the conjugal transfer of DNA from Escherichia coli to Streptomyces spp. Gene 116: 43 49, 1992

28) TSAI, J. F.-Y. \& C. W. CHEN: Isolation and characterization of Streptomyces lividans mutants deficient in intraplasmid recombination. Mol. Gen. Genet. 208: $211 \sim 218,1987$

29) CARney, J. R.; S.-T. Hong \& S. J. Gould: Seongomycin: a new sulfur-containing benzo $[b]$ fluorene derived from genes clustered with those for kinamycin biosynthesis. Tetrahedron Lett. 38: 3139 3142, 1997

30) Sato, Y.; R. Kohnert \& S. J. Gould: Application of long-range ${ }^{1} \mathrm{H} /{ }^{13} \mathrm{C}$ heteronuclear correlation spectroscopy (LR HETCOSY) to structure elucidation: the structure of murayaquinone. Tetrahedron Lett. 27: $143 \sim 146,1986$

31) Hong, S.-H.; J. R. Carney \& S. J. Gould: Cloning and heterologous expression of the entire gene clusters for PD 116740 from Streptomyces WP 4669 and tetrangulol and tegrangomycin from Streptomyces rimosus NRRL 3016. J. Bacteriol. 179: 470 476, 1997

32) Kuntsmann, M. P. \& L. A. Mitscher: The structural characterization of tetrangomycin and tetrangulol. J. Org. Chem. 31: 2920 2925, 1966

33) Wilton, J. H.; D. C. Cheney, G. C. Hokanson \& J. C. FRENCH: A new dihydrobenz $[a]$ anthraquinone antitumor antibiotic (PD 116740). J. Org. Chem. 50: 3936 3938, 1985

34) Malpartida, F. \& D. A. Hopwood: Physical and genetic characterisation of gene cluster for the antibiotic actinorhodin in Streptomyces coelicolor A3(2). Mol. Gen. Genet. 205: 66 73, 1986

35) Davis, N. K. \& K. F. Chater: Spore colour in Streptomyces coelicolor A3(2) involves the developmentally regulated synthesis of a compound biosynthetically related to polyketide antibiotics. Mol. Microbiol. 4: 1679 1692, 1990

36) YU, T.-W. \& D. A. Hopwood: Ectopic expression of the Streptomyces coelicolor whiE genes for polyketide spore pigment synthesis and their interaction with the act genes for actinorhodin biosynthesis. Microbiology 141: 2779 2791,1995

37) DeCKer, H. \& S. HAaG: Cloning and characterization of a polyketide synthase gene from Streptomyces fradiae Tü 2717, which carries the genes for biosynthesis of the angucycline antibiotic urdamycin A and a gene probably involved in its oxygenation. J. Bacteriol. 177: 6126 6136, 1995

38) Gould, S. J.; C. R. Melville \& J. Chen: The biosynthesis of murayaquinone, a rearranged polyketide. Tetrahedron 53: $4561 \sim 4568,1997$

39) Yang, K.; L. Han, S. W. Ayer \& L. C. Vining: Accumulation of the angucycline antibiotic rabelomycin after disruption of an oxygenase gene in the jadomycin B biosynthetic gene cluster of Streptomyces venezuelae. Microbiology 142: 123 132, 1996 